\title{
Mountain Child: Systematic Literature Review
}

\author{
Annie Audsley $^{1} \cdot$ Rebecca M. M. Wallace ${ }^{2} \cdot$ Martin F. Price ${ }^{3}$
}

Published online: 11 July 2016

(C) The Author(s) 2016. This article is published with open access at Springerlink.com

\begin{abstract}
Objectives This systematic review identifies and reviews both peer-reviewed and 'grey' literature, across a range of disciplines and from diverse sources, relating to the condition of children living in mountain communities in low- and middle-income countries. Findings The literature on poverty in these communities does not generally focus on the particular vulnerabilities of children or the impact of intersecting vulnerabilities on the most marginalised members of communities. However, this literature does contribute analyses of the broader context and variety of factors impacting on human development in mountainous areas. The literature on other areas of children's lives-health, nutrition, child mortality, education, and child labour-focuses more specifically on children's particular vulnerabilities or experiences. However, it sometimes lacks the broader analysis of the many interrelated characteristics of a mountainous environment which impact on children's situations. Themes Nevertheless, certain themes recur across many disciplines and types of literature, and point to some general conclusions: mountain poverty is influenced by the very local specificities of the physical environment; mountain communities are often politically and economically marginalised, particularly for
\end{abstract}

Rebecca M. M. Wallace

r.m.m.wallace@rgu.ac.uk

Annie Audsley

annie.audsley26@gmail.com

Martin F. Price

Martin.Price.perth@uhi.ac.uk

Edinburgh, UK

The Robert Gordon University, Aberdeen, UK

3 University of the Highlands and Islands, Perth, UK the most vulnerable within these communities, including children; and mountain communities themselves are an important locus for challenging and interrupting cycles of increasing inequality and disadvantage. While this broadscale review represents a modest first step, its findings provide the basis for further investigation.

Keywords Literature review - Mountain · Child .

Wellbeing · Poverty $\cdot$ Health $\cdot$ Nutrition · Education $\cdot$ Child mortality $\cdot$ Child labour/child labor

\section{Significance}

The review compares literature from across disciplines and geographical locations to look at the effect on children of growing up in a mountainous environment. The significance is in the finding of common themes across the literature, which tend to confirm the broad applicability of Ives' description of a "mountain problematique" [27, p. 10].

What this study adds: Geographic specificity is important in understanding mountain poverty and most of the literature reviewed here focuses on specific geographic areas and the local determinants of poverty. However this review takes a comparative perspective in order to examine whether mountainous environments also have a general effect on child poverty.

\section{Context, Aim and Objectives}

Mountains cover 22 percent of the Earth's land surface and are home to 13 percent of its population [54]. Of these 915 million people (in 2012), 39 percent in developing countries are considered vulnerable to food insecurity: a 30 
percent increase since 2000 [26], while the mountain population has increased by only 16 percent. Arguably, therefore, the vulnerability of mountain people is increasing, and the "mountain problematique" identified by Ives [27, p. 10, 28] two decades ago is intensifying. Ives argued that this situation is due to the combination of marginal ecosystems; remoteness and cultural or ethnic distinctiveness, sometimes compounded by environmental degradation; natural hazards; globalisation; and, often, conflict. The disproportionate effect of poverty on women and, in turn, on children leads to the mountain girl child being the "most vulnerable member of humankind" [27, p. 29]. Ives [27] urgently called for further research on the situation of children in mountain communities.

The aim of this review was to test whether the existing literature confirms Ives' view that children in mountainous environments in low- and middle-income countries are disadvantaged compared with lowland children in the same country or region. Based on his description of the "mountain problematique", a wide variety of interconnected factors impacting on mountain children was anticipated. The objective was to identify and gather evidence which could provide insights into how growing up in a mountainous environment affects children. Specifically, the review hoped to identify, first, how and why such children may be materially affected and, second, crosscutting themes in authors' discussions of these impacts. The project's scope was broad rather than deep: the intention was to use literature from different disciplines to identify the range of factors which could impact on children's wellbeing, and to describe themes which recur across disciplines and world regions, in order to provide a context within which to understand the condition of children in mountainous environments and suggest themes for further investigation.

\section{Methods}

Web searches were used to identify documents from a variety of sources: peer-reviewed journals covering a range of disciplines, and reports from research centres, NonGovernmental Organisations (NGOs) and United Nations (UN) agencies. Search terms were usually "child AND mountain OR highland", the only exceptions being databases which focus on either children or mountains. For example, the search term used for the Mountain Forum online library was simply "child." An iterative approach [43] was used, "snowballing" searches to look at references from literature that had already been identified and sourcing other papers by known authors. The full search plan for the review is included as an "Appendix".

Eligibility criteria for inclusion in the review were broad. Any article or report, published or unpublished, which revealed anything about a relationship between mountainous environments and the condition of children was included. Documents that simply mentioned that the study took place in a mountainous environment or did not engage with the question of how the mountainous context impacted on children's wellbeing were excluded from the review. The selection was limited to studies in English written since 2000 , both to provide a contemporary view and because of limited resources. Documents which met the eligibility criteria were selected for review by reading the abstract and, where necessary, scanning the entire document.

The initial web searches identified 165 documents, from which 68 were selected for the review by reference to the eligibility criteria. The table below gives a breakdown of documents which were selected, according to topic and type of document (Table 1).

Given the diverse sources, analysis or comparison of empirical data was not relevant; instead, the discussion is based on the authors' conclusions and observations. For each document, notes were made and brief summaries written, drawing out any evidence or discussion which addressed the impact of mountainous environments on children. A spreadsheet was then used to categorise documents into broad topics (see table above) and themes (driving forces). These themes were assessed according to the frequency with which they recurred in the literature, particularly across documents on different topics. For example, marginalisation featured in discussions on poverty, health, nutrition, education and child labour.

The review was carried out by two individuals. One completed the preliminary search, selected documents for review, read and took notes. The two individuals then worked together to identify themes, discuss conclusions, and write this paper.

\section{Discussion}

This discussion begins with an examination of literature on different topics: poverty, health, nutrition, child mortality, education, and child labour; then going on to identify some crosscutting themes. References are cited with regard to specific themes. They are also included in the list of references at the end of the article.

\section{Poverty}

Literature on mountain poverty gives contextual and explanatory frameworks for understanding the situation of children in mountain communities. No literature focusing specifically on both mountainous environments and child poverty was identified, other than [27, 28]. However, the use of child indicators, such as school enrolment and infant 
Table 1 Document sources and topics

\begin{tabular}{|c|c|c|c|c|c|c|}
\hline Topic & $\begin{array}{l}\text { Peer reviewed journal } \\
\text { articles }\end{array}$ & $\begin{array}{l}\text { UN/Gov/intergov org } \\
\text { publications }\end{array}$ & $\begin{array}{l}\text { NGO } \\
\text { publications }\end{array}$ & $\begin{array}{l}\text { Development bank } \\
\text { publications }\end{array}$ & $\begin{array}{l}\text { Other (book chapters, } \\
\text { partnerships) }\end{array}$ & Total \\
\hline General & 0 & 1 & 2 & 1 & 0 & 4 \\
\hline Poverty & 0 & 4 & 1 & 3 & 4 & 12 \\
\hline Health & 6 & 1 & 3 & 0 & 1 & 11 \\
\hline Nutrition & 13 & 2 & 0 & 0 & 1 & 16 \\
\hline $\begin{array}{l}\text { Child } \\
\text { mortality }\end{array}$ & 6 & 0 & 0 & 0 & 0 & 6 \\
\hline Education & 4 & 2 & 4 & 2 & 2 & 14 \\
\hline $\begin{array}{l}\text { Child } \\
\text { labour }\end{array}$ & 3 & 2 & 0 & 0 & 0 & 5 \\
\hline Total & 32 & 12 & 10 & 6 & 8 & 68 \\
\hline
\end{tabular}

mortality rate (IMR), enables some analysis of the effects of mountainous environments on child poverty.

Findings in the literature are varied, and suggest that the effects of mountainous environments on child poverty are not straightforward; many other factors have an influence. Most documents do conclude that mountainous environments have a negative impact on the economic situation and human development of mountain communities; some literature explicitly theorises the concept of place, interpreting geographic location as the primary determinant of poverty and well-being. Explanatory factors include remoteness and geographic conditions (Bird et al. [8], introducing a typology of "remote rural areas"; Ssewaya [62], on a mountainous area of Uganda; Jolliffe [29], on Afghanistan; UNICEF [64], on Lesotho; Gerlitz et al. [22], looking at determinants of mountain poverty across the Hindu Kush Himalayas); cultural or ethnic distinctiveness or social-political exclusion (Baulch et al. [6], Dang 15], both on Vietnam); environmental degradation [22]; and lack of access to external markets (Joshi [30] on Himalayan states of India). All of these factors can be exacerbated by the effects of rapid economic, social and climatic change (Walker [67], on childhood vulnerability to climate change in mountainous areas of Vietnam; Gerlitz et al. [22]). The fragile balance can also be more catastrophically upset by natural disasters or violent conflict, both of which are often characteristic of mountainous regions [27], with impacts on all aspects of children's lives (Asian Development Bank and World Bank [2], on the impact of the 2005 earthquake in Pakistan; Mohamed et al. [42], on the impacts of violent conflict in the central highlands of Papua province, Indonesia).

Other studies present a more varied picture, illustrating the complexity of mountain poverty: mountainous areas are not always poorer than lowlands. For example, a report on poverty in Nepal [3] finds that the Mountain and Terai (lowland) regions consistently have the worst child poverty indicators and the Hill (mountain) regions, by most measures, fare better. Similarly, a study of poverty in four sites in Ethiopia for Oxfam [65], covering both lowlands and highlands, described the former as "remote", with access to health services and schools no better than in rural highland areas.

The literature cited above shows how mountainous environments can often have negative impacts on human development across a wide range of indicators, but none of these documents thoroughly explore the particular vulnerability of children in these environments. The literature reviewed in the following sections does focus more specifically on children, but often without the wider contextualisation provided by the literature on poverty.

\section{Health}

The literature on health services reveals a number of problems regarding access to these services in mountain communities, with impacts on children's health. Perhaps most common is the impact of geographical remoteness on access to such services (Singh [61], on the Tibetan Autonomous Region; Gyaltsen et al. [23], on Qinghai Province, China; literature review on access to and use of health services in mountainous regions by Byrne et al. [9]. In contrast, one study from Ethiopia describes greater remoteness and worse health outcomes in the lowlands compared to the highlands [55]. Remoteness is not the only factor leading to poor access to services: political priorities and individuals' decisions over the use of services are also relevant (Singh [61] and Morris [44], on uptake of health services in Honduras; Van Vo et al. [66], on the use of maternal health care services in Vietnam; Rheinländer et al. [52], on care-seeking practices in Vietnam; Oxfam [47], on provision of healthcare services in Nepal; Byrne et al. [9]).

Children living in mountain communities also face risks to their health related to their location, such as increased 
risk of pneumonia and respiratory infections at high altitudes (Khan et al. [31], on Pakistan; literature review on child health at altitude by Niermeyer et al. [45]); risks of injury (Shi et al. [58], on South-west China); or the increased risks of natural disasters (Chohan [12], on the impact of flooding in Khyber Pakhtunkhwa and Punjab, Pakistan). Other risks to children's health relate to the wider context of poverty in mountain communities, as discussed above [23].

\section{Nutrition}

Many studies identify a nexus between mountainous areas and child malnutrition (Leonard et al. [35], Larrea and Kawachi [33]; Rogers et al. [53], on Ecuador; Harris et al. [25], Dang et al. [16, 17], on Tibetan children; San Miguel et al. [56], on Bolivia; Dutta and Pant [19], on the Garhwal Himalayas; Larrea et al. [34], on the Andes; Miyoshi et al. [41], on the Lao PDR; Wang et al. [68], on rural North West China). While unfavourable geographical conditions seem to be a large contributory factor [56, 19, 34, 41, 68], other factors, such as lack of healthcare facilities [25], economic inequality [33], maternal education [68] and cultural factors [17] also have effects. The impacts of poverty and hardship on early feeding practices [32] are also relevant.

Mountainous regions tend to be characterised by deficiencies of micronutrients, primarily iodine and iron, and specific deficiencies are associated with particular mountainous areas [26]. Micronutrient deficiencies are associated with significant health problems (Zimmermann et al. [71], on the interaction between iodine and iron deficiency in a mountainous region of Côte d'Ivoire; Oberlin et al. [46], on goitre and iodine deficiency in Afghanistan; Singh and Choudhary [60], on the health impacts of anaemia on teenage girls in the Himalayas; Counter et al. [13], on the impact of anaemia and lead exposure on the hearing of children living at high altitude in the Andes).

\section{Child Mortality}

Child mortality (particularly infant mortality) is often used as an indicator of poverty or health. Of the literature discussed above, several studies suggest that high IMRs are associated with mountainous areas. For example, studies in the Tibetan Autonomous Region [61] and Vietnam [15] both describe IMRs that are significantly higher in mountain areas than at national levels in the respective countries.

High rates of child mortality often appear to be related to generally poor levels of human development which, in turn, characterise mountainous areas (Manandhar et al. [39], on Nepal; Wellhoner et al. [69], on Qinghai Province, China). A study conducted in Ladakh [70], found that altitude per se is a specific factor, combined with the fact that the population has a relatively short ancestry in the area and may not have developed genetic adaptations to living at altitude. In contrast, Chin et al. [10] find that in Nepal, altitude is statistically a protective factor, when controlling for other known factors.

De Hilari et al. [18] examine infanticide in two highland villages in Bolivia and suggest that it could be related to poverty and isolation.

\section{Education}

Children can face many problems in receiving education in mountainous areas. Possibly most notable are the physical accessibility and quality of schools in remote areas (Fung [21], on mountainous areas of China; Postiglione [50], on Tibet; Siaens and Goyal [59], on Bhutan), which can be exacerbated by other overlapping vulnerabilities (Barriga [5], on access to education for children with disabilities in Nepal; Choden [11], finds that poverty affects school attendance and enrolment in Bhutan). However, a meaningful education also requires that schools are linguistically and culturally appropriate (Middleborg [40], on Ratanakiri Province in Cambodia, Postiglione [50], on Tibet; Bangsbo [4], on the Tibetan regions of Sichuan and Qinghai Provinces). Political will and policy frameworks allowing for diversity are vital to ensure the provision of education which is accessible, appropriate and of good quality [40]. Where government acceptance of diversity is lacking, education can become an arena of conflict over identity (Arquiza [1], on the education of ethnic minority children in a mountainous region of the Philippines).

A number of studies examine the impact of gender equality on school enrolment or attendance. Their findings are quite mixed: while some studies associate gender inequality with mountainous areas (UNDP [63], on the Lao PDR; Oxfam [48], on Afghanistan; Parker et al. [49], on Nepal), others find that national-level characteristics are more influential than the difference between mountain and lowland areas (Hannum and Adams [24], on Gansu Province in China where gender inequality is declining; Lloyd et al. [37], Lloyd and Ghuman [36], on Pakistan where the gender gap is wide in poor, rural, and remote areas of both mountains and lowlands).

\section{Child Labour}

Child labour is another major factor impacting on children's educational outcomes, health and wellbeing. Several studies describe the prevalence of child labour in mountainous regions and its association with poverty, remoteness and marginalised communities, in particular those communities experiencing increased pressures from rapid 
economic or environmental change (Sherchan [57], on children in mountain communities in Nepal; Dammert [14], on child labour in Peru following a rapid reduction in coca production). Prasun and Kainthola [51] describe how, in circumstances of extreme inequality and marginalisation in a remote area of Uttarakhand, India, children are vulnerable to bonded labour and trafficking. In contrast, another study in Uttarakhand [38] suggests that environmental degradation which threatens traditional livelihoods has led to an increased perception of the need for education and in turn, increased school enrolment.

\section{Themes}

The discussion now turns to certain characteristics of mountainous environments which were recurring themes across the reviewed documents.

\section{Physical Environment}

The literature makes clear that mountain communities are affected by very specific local conditions and that spatial or geographic factors are key determinants in mountain poverty. Several recent studies have been able to map poverty indicators at a much more local level than previously, enabling a better understanding of specific geographic factors [53, 10, 68]). Mountain poverty is therefore complex and varied, and an understanding of the specific local conditions is vital in order to help develop appropriate interventions (Bayoumi [7], on a community-based birth registration project in the Nuba mountains in Sudan; Walker [67]; Gerlitz et al. [22]).

\section{Marginalisation and External Influence}

Many studies state that mountain communities tend to be politically and economically marginalised, often because they are ethnically or linguistically distinct from lowland urban and political centres [4, 20, 25, 33, 52]. Such marginalised communities are more vulnerable to the additional stressors created by economic, social or environmental and climactic changes (e.g. [30], on the negative influence of market liberalisation; [19], on the downward spiral of poverty and environmental degradation). Many studies also consider intersecting vulnerabilities based on caste, class, gender and-of particular relevance here-generation, creating conditions of particular disadvantage for the most vulnerable members within mountain communities [20, 22, 49, 67]. Consequently, many advocate a child rights based approach [47, 48, 61, 67] and investment in improved accessibility, quality, and cultural appropriateness of services $[1,9,50,52,66,69]$.

\section{Mountain Communities}

Mountain communities themselves can contribute not only to the perpetuation of disadvantage but also to its interruption. Isolated communities can be associated with harmful cultural practices (eg infanticide: De Hilari et al. [18]) or traditional beliefs and social relations which maintain inequality and disadvantage among sections of the community. For example, the negative impact on children's wellbeing of gender inequality is a frequently recurring theme [20, 47-49, 52, 60, 63, 66]. However, much of the literature points to the agency of communities and of children themselves in challenging traditional practices and beliefs [49, 22] and in adapting to external pressures such as climate change [67] or constructing meaning and self-respect within their current situation [20]. Going beyond the scope of this review on the impacts of mountainous environments on children's material wellbeing, the recurring theme of the strength and importance of mountain communities and, in particular, Dyson's work, suggests that an alternative line of investigation could look at non-material effects such as mental health and wellbeing, constructed meanings, and identities.

\section{Conclusions}

This review has examined literature across many disciplines and publications. Peer-reviewed articles range from statistical analysis of health outcomes to ethnographic and qualitative studies looking in greater depth at children's individual experiences. The reports of NGOs and UN agencies often have a more straightforward analysis based on their particular agendas. While bias is a possibility in some of these publications, nonetheless they provide insights into the condition of children in mountainous environments.

The literature tends to support the view of Ives [27, 28] that children are, in general, negatively affected by living in mountainous environments in low- and middle-income countries. The literature on poverty does not generally focus on the particular vulnerabilities of children or the impact of intersecting vulnerabilities on the most marginalised members of communities. Exceptions were Walker [67], Gerlitz et al. 22], who account for intersecting vulnerabilities in their analyses. However, the literature on poverty does contribute analyses of the broader context and variety of factors impacting on human development in mountainous areas. 
The literature on other areas of children's lives-health, nutrition, child mortality, education, and child labour-is more specifically focussed on children's particular vulnerabilities or experiences. However, it sometimes lacks the broader analysis of the many interrelated characteristics of a mountainous environment which impact on children's situations. Nevertheless, themes were identified which recur across many disciplines and types of literature and point to some general conclusions: mountain poverty is influenced by the very local specificities of the physical environment; mountain communities are often politically and economically marginalised, which is exacerbated for the most vulnerable within the communities, including children; and mountain communities themselves are an important locus for challenging and interrupting cycles of increasing inequality and disadvantage.

The limitations of this study are that it sacrificed depth of analysis, comparability of results, and assessment of the quality of individual studies for a broader view of the context and the identification of themes which cut across disciplines. The global perspective adopted is also at the cost of investigating the geographical specificity of any one region. The rationale for this wide scope was to focus on the impact of mountainous environments per se rather than to look in depth at any one community or region, as a wide range of examples was needed to test the broad applicability of Ives' postulate. Nevertheless, this review represents a modest first step, providing a range of findings which provide the basis for further investigation.

Open Access This article is distributed under the terms of the Creative Commons Attribution 4.0 International License (http://crea tivecommons.org/licenses/by/4.0/), which permits unrestricted use, distribution, and reproduction in any medium, provided you give appropriate credit to the original author(s) and the source, provide a link to the Creative Commons license, and indicate if changes were made.

\section{Appendix: Online Searches}

\begin{tabular}{|c|c|c|}
\hline Organisation & Web address & Search terms \\
\hline \multicolumn{3}{|l|}{ Journals/Databases/Research Centres } \\
\hline Taylor Francis Journals & http://www.tandfonline.com & $\begin{array}{l}\text { Child AND mountain OR } \\
\text { highland }\end{array}$ \\
\hline Oxford Journals & http://services.oxfordjournals.org & $\begin{array}{l}\text { Child AND mountain OR } \\
\text { highland }\end{array}$ \\
\hline Bio One Online Journals & http://www.bioone.org/action/doSearch & $\begin{array}{l}\text { Child AND mountain OR } \\
\text { highland }\end{array}$ \\
\hline Mountain Forum & http://www.mtnforum.org/publications & Child \\
\hline Lancet & http://www.thelancet.com & $\begin{array}{l}\text { Child AND mountain OR } \\
\text { highland }\end{array}$ \\
\hline Elsevier & http://www.journals.elsevier.com & $\begin{array}{l}\text { Child AND mountain OR } \\
\text { highland }\end{array}$ \\
\hline Nature Publishing Group & http://www.nature.com & $\begin{array}{l}\text { Child AND mountain OR } \\
\text { highland }\end{array}$ \\
\hline Science Direct & http://www.sciencedirect.com & $\begin{array}{l}\text { Child AND mountain OR } \\
\text { highland }\end{array}$ \\
\hline $\begin{array}{l}\text { Chronic Poverty Research Centre, Manchester } \\
\text { University }\end{array}$ & http://www.chronicpoverty.org/search & $\begin{array}{l}\text { Child AND mountain OR } \\
\text { highland }\end{array}$ \\
\hline $\begin{array}{l}\text { Childhood Poverty Research and Policy } \\
\text { Centre (CHIP) }\end{array}$ & http://www.childhoodpoverty.org/index.php & Mountain OR highland \\
\hline \multicolumn{3}{|l|}{ UN Agencies } \\
\hline UNICEF & http://www.unicef.org/search & Mountain OR highland \\
\hline World Health Organization & http://apps.who.int/iris/ & $\begin{array}{l}\text { Child AND mountain OR } \\
\text { highland }\end{array}$ \\
\hline ILO & http://www.ilo.org/global/publications/books & Child labour / labor \\
\hline UNESCO & $\begin{array}{l}\text { http://www.unesco.org/new/en/unesco/resources/publications/ } \\
\text { unesdoc-database/ }\end{array}$ & $\begin{array}{l}\text { Child AND mountain OR } \\
\text { highland }\end{array}$ \\
\hline UNDP & http://www.undp.org/content/undp/en/home/librarypage.html & $\begin{array}{l}\text { Child AND mountain OR } \\
\text { highland }\end{array}$ \\
\hline World Bank & http://www.worldbank.org/reference/ & $\begin{array}{l}\text { Child AND mountain OR } \\
\text { highland }\end{array}$ \\
\hline Food and Agricultural Organization. & http://www.fao.org/publications/search/en/ & Mountain \\
\hline
\end{tabular}




\begin{tabular}{llc}
\hline Organisation & Web address & Search terms \\
\hline NGOs & & Child AND mountain OR \\
Human Rights Watch & http://www.hrw.org/publications/reports & Mighd \\
Plan & http://plan-international.org/about-plan/resources/publications & Child AND mountain OR \\
Oxfam GB & http://policy-practice.oxfam.org.uk/publications & highland highland \\
Save the Children & http://www.savethechildren.org.uk/resources/online-library & Mountain OR highland \\
\hline
\end{tabular}

\section{References}

1. Arquiza, M. S. Q. (2006). Philippine ethnic and Muslim minorities: Educating children the traditional way. Mountain Research and Development, 26(1), 24-27.

2. Asian Development Bank and World Bank. (2005). Pakistan 2005 earthquake: Preliminary damage and needs assessment. World Bank. http://www-wds.worldbank.org/external/default/WDSCon tentServer/WDSP/IB/2005/11/18/000160016_20051118124031/ Rendered/PDF/34407.pdf. Accessed April 19, 2012.

3. Asian Development Bank and International Centre for Integrated Mountain Development. (2006). Rural environment, poverty and livelihood. In Environment assessment of Nepal emerging issues and challenges. Kathmandu: Asian Development Bank/ICIMOD.

4. Bangsbo, E. (2008). Schooling for knowledge and cultural survival: Tibetan community schools in nomadic herding areas. Educational Review, 60(1), 69-84.

5. Barriga, S. R. (2011). Futures Stolen: Barriers to education for children with disabilities in Nepal. New York: Human Rights Watch.

6. Baulch, B. et al. (2010). Ethnic minority poverty in Vietnam. CPRC Working Paper No. 169. Manchester: Chronic Poverty Research Centre.

7. Bayoumi, A. (2006). Maternal and childhood mortality in the Nuba Mountains, Sudan: A pilot study. Sudanese Journal of Public Health, 1(1), 21-26.

8. Bird, K. D. et al. (2002). Chronic poverty and remote rural areas. CPRC Working Paper No. 13. Manchester: Chronic Poverty Research Centre.

9. Byrne, A., et al. (2014). What works? Strategies to increase reproductive, maternal and child health in difficult to access mountainous locations: A systematic literature review. PLoS ONE, 9(2), e87683. doi:10.1371/journal.pone.0087683.

10. Chin, B., Montanab, L., \& Basagañac, X. (2011). Spatial modeling of geographic inequalities in infant and child mortality across Nepal. Health \& Place, 17(4), 929-936.

11. Choden, T., et al. (2014). The education resilience of out-ofschool children in Bhutan: A methodology and pilot study. Washington, DC: World Bank.

12. Chohan, N. (2011). Psychological assessment report: Psychosocial problems and needs of children in flood affected areas in Pakistan. Save the Children. https://www.savethechildren.org.uk/ resources/online-library/psychological-assessment-report-psycho social-problems-and-needs-children. Accessed April 15, 2012.

13. Counter, S. A., Buchanan, L. H., \& Ortega, F. (2012). Association of hemoglobin levels and brainstem auditory evoked responses in lead-exposed children. Clinical Biochemistry, 45(15), 1197-1201.

14. Dammert, A. (2008). Child labor and schooling response to changes in coca production in rural Peru. Journal of Development Economics, 86(1), 164-180.

15. Dang, H. (2010). Growth in Vietnam is strong but not shared equitably across ethnic groups. Indigenous Peoples country brief No. 1. Washington, DC: World Bank.
16. Dang, S., et al. (2004). Poor nutritional status of younger Tibetan children living at high altitudes. European Journal of Clinical Nutrition, 58, 938-946.

17. Dang, S., et al. (2005). Feeding practice among younger Tibetan children living at high altitudes. European Journal of Clinical Nutrition, 59, 1022-1029.

18. De Hilari, C., Condori, I., \& Dearden, K. A. (2009). When is deliberate killing of young children justified? Indigenous interpretations of infanticide in Bolivia. Social Science and Medicine, $68(2), 352-361$.

19. Dutta, A., \& Pant, K. (2003). The nutritional status of indigenous people in the Garhwal Himalayas, India. Mountain Research and Development, 23(3), 278-283.

20. Dyson, J. (2008). Harvesting Identities: Youth, Work, and Gender in the Indian Himalayas. Annals of the Association of American Geographers, 98(1), 160-179. doi:10.1080/ 00045600701734554.

21. Fung, K. (2008). Oxfam Hong Kong's advocacy work on relocation of rural schools in China. Oxfam International. http:// policy-practice.oxfam.org.uk/publications/oxfam-hong-kongsadvocacy-work-on-relocation-of-rural-schools-in-china-112449. Accessed April 19, 2012.

22. Gerlitz, J.-Y., et al. (2014). Poverty and vulnerability assessment: A survey instrument for the Hindu Khush Himalayas. Kathmandu: ICIMOD.

23. Gyaltsen, K., et al. (2007). Socioeconomic status and maternal and child health in rural Tibetan villages. Los Angeles: California Center for Population Research.

24. Hannum, E., \& Adams, J. (2007). Girls in Gansu, China: Expectations and aspirations for secondary schooling. In M. Lewis \& M. Lockheed (Eds.), Exclusion, gender and education: Case studies from the developing world (pp. 71-98). Washington, DC: Centre for Global Development.

25. Harris, N., et al. (2001). Nutritional and health status of Tibetan children living at high altitudes. New England Journal of Medicine, 344(5), 341-347.

26. Huddleston, B., Ataman, E., \& Fè D'ostiani, L. (2003). Towards a GIS-based analysis of mountain environments and populations. Rome: FAO.

27. Ives, J. D. (1996). Children women and poverty in mountain ecosystems. New York: UNICEF.

28. Ives, J. D. (1997). Comparative inequalities-Mountain communities and mountain families. In J. D. Ives \& B. Messerli (Eds.), Mountains of the world: A global priority. New York: Parthenon Publishing Group.

29. Jolliffe, D. (2010). Poverty Status in Afghanistan: A profile based on the National Risk and Vulnerability Assessment (NRVA) 2007/08. Washington, DC: World Bank.

30. Joshi, B. K. (2000). Development experience in the Himalayan mountain region of India. In M. Banskota, T. S. Papola, \& J. Richter (Eds.), Growth, poverty alleviation and sustainable resource management in the mountain areas of South Asia (pp. 
171-194). Feldafing: Deutsche Stiftung fur Internationale Entwicklung Zentralstelle fur Ernahrung und Landwirtschaft.

31. Khan, A. J., et al. (2009). High incidence of childhood pneumonia at high altitudes in Pakistan: A longitudinal cohort study. Bulletin of the World Health Organization, 87(3), 193-197. doi:10.2471/ BLT.07.048264.

32. Khanal, V. et al. (2013). Exclusive breastfeeding practices in relation to social and health determinants: A comparison of the 2006 and 2011 Nepal Demographic and Health Surveys. BMC Public Health, 13, 958. doi:10.1186/1471-2458-13-958.

33. Larrea, C., \& Kawachi, I. (2005). Does economic inequality affect child malnutrition? The case of Ecuador. Social Science and Medicine, 60(1), 165-178.

34. Larrea, C., Montalvo, P., \& Ricaurte, A. M. (2004). Child malnutrition, social development and health services in the Andean region. Quito: Facultad Latinoamericana de Ciencias Sociales (FLACSO).

35. Leonard, W. R., et al. (2000). Influence of dietary quality on the growth of highland and coastal Ecuadorian children. American Journal of Human Biology, 12(6), 825-837.

36. Lloyd, C., \& Ghuman, S. (2007). Teacher absence as a factor in gender inequalities in access to primary schooling in rural Pakistan. Poverty, Gender and Youth Working Paper No. 1. New York: The Population Council.

37. Lloyd, C., Mete, C., \& Grant, M. (2007). Rural girls in Pakistan: Constraints of policy and culture. In M. Lewis \& M. Lockheed (Eds.), Exclusion, gender and education: Case studies from the developing world (pp. 99-118). Washington, DC: Centre for Global Development.

38. Makino, Y. (2011). Lopping of oaks in Central Himalaya, India. Mountain Research and Development, 31(1), 35-44.

39. Manandhar, D., et al. (2004). Effect of a participatory intervention with women's groups on birth outcomes in Nepal: Clusterrandomised controlled trial. Lancet, 364(9438), 970-979.

40. Middleborg, J. (2005). Highland children's education project: A pilot project on bilingual education in Cambodia. Bangkok: UNESCO Bangkok.

41. Miyoshi, M., et al. (2005). Nutritional status of children in rural Lao PDR: Who are the most vulnerable? European Journal of Clinical Nutrition, 59, 887-890.

42. Mohamed, C., et al. (2007). Out of sight: Endemic abuse and impunity in Papua's central highlands. New York: Human Rights Watch.

43. Moher D, Liberati A, Tetzlaff J, Altman DG, The PRISMA Group. (2009). Preferred reporting items for systematic reviews and meta-analyses: The PRISMA statement. PLoS Med, 6(7), e1000097. doi:10.1371/journal.pmed.1000097.

44. Morris, S., et al. (2004). Monetary incentives in primary health care and effects on use and coverage of preventive health care interventions in rural Honduras: Cluster randomised trial. Lancet, 364(9450), 2030-2037.

45. Niermeyer, S., Mollinedo, P. A., \& Huicho, L. (2009). Child health and living at high altitude. Archives of Disease in Childhood, 94(10), 806-811.

46. Oberlin, O., et al. (2006). Goitre and iodine deficiency in Afghanistan: A case-control study. British Journal of Nutrition, 95, 196-203.

47. Oxfam UK. (2013). My rights my voice nepal project overview. Oxfam. http://policy-practice.oxfam.org.uk/publications/my-rightsmy-voice-nepal-project-overview-305546. Accessed March 19, 2015.

48. Oxfam UK. (2013). My rights my voice Afghanistan project overview. Oxfam. http://policy-practice.oxfam.org.uk/publications/myrights-my-voice-afghanistan-project-overview-305510. Accessed March 19, 2015.
49. Parker, S., et al. (2014). 'My grandfather broke all traditional norms by sending both his daughters to school': Lessons from 'inspirational' women in Nepal. Gender \& Development, 22(1), 91-108. doi:10.1080/13552074.2014.889272.

50. Postiglione, G. A. (2008). Making Tibetans in China: The educational challenges of harmonious multiculturalism. Educational Review, 60(1), 1-20.

51. Prasun, K., \& Kainthola, S. (2002). Bonded labour and trafficking of girl-child among the Kolta: A case study. Kathmandu: ICIMOD.

52. Rheinländer, T., et al. (2011). Perspectives on child diarrhoea management and health service use among ethnic minority caregivers in Vietnam. BMC Public Health,. doi:10.1186/14712458-11-690.

53. Rogers, B. L. et al. (2007). Mapping hunger in Ecuador: A Report on mapping malnutrition prevalence. Boston, MA: World Food Programme and Gerald J and Dorothy R Friedman School of Nutrition Science and Policy, Tufts University.

54. Romeo, R., Vita, A., Testolin, R., \& Hofer, T. (2015). Mapping the vulnerability of mountain peoples to food insecurity. Rome: FAO.

55. Russell, S., \& Abdella, K. (2002). Too poor to be sick: Coping with the costs of illness in East Hararghe, Ethiopia. London: Save the Children UK. https://www.savethechildren.org.uk/ resources/online-library/too-poor-to-be-sick-coping-with-thecosts-of-illness-in-east-hararghe-ethiopia. Accessed April 20, 2012.

56. San Miguel, J. L., et al. (2002). Effect of high altitude on protein metabolism in Bolivian children. High Altitude Medicine and Biology, 3(4), 377-386.

57. Sherchan, U. (2001). Mountain children of Nepal: A lost generation. Kathmandu: ICIMOD.

58. Shi, X.-Q., et al. (2014). Features and risk factors of nonfatal injury among the rural children: A survey of seven schools in a mountain area in southwest China. PLoS ONE,. doi:10.1371/ journal.pone.0102099.

59. Siaens, C., \& Goyal, S. (2009). Findings from the Bhutan Learning Quality Survey. Washington, DC: World Bank.

60. Singh, R., \& Choudhary, V. S. (2007). Anaemia in young girls: The silent killer of the Central Himalayas. Kathmandu: ICIMOD.

61. Singh, S. (2004). Tears from the land of snow: Health and human rights in Tibet. Lancet, 364(9438), 1009.

62. Ssewaya, A. (2003). Dynamics of chronic poverty in remote rural Uganda. Manchester: Chronic Poverty Research Centre.

63. UNDP. (2010). Unlocking progress: MDG acceleration on the road to 2015. New York: UNDP.

64. UNICEF. (2012). Draft Country Programme Document: Lesotho. http://www.unicef.org/about/execboard/files/Lesotho-2013-2017final_approved-English-14Sept2012.pdf. Accessed February 28, 2015.

65. Von Massow, F. (2001). Access to health and education services in Ethiopia: Supply, demand and government policy. Oxford: Oxfam GB.

66. Van Vo, T., Hoat, L. N., \& Jan van Schie, T. (2004). Situation of the Kinh poor and minority women and their use of the maternal care and family planning service in Nam Dong mountainous district, Thuathien-Hue Province, Vietnam. Rural and Remote Health, 4, 255

67. Walker, D. (2012). Childhood vulnerability to climate change in marginalised Vietnamese communities: The case for participation. London: Overseas Development Institute/Plan International. http:// www.odi.org/publications/6881-childhood-vulnerability-climatechange-marginalised-vietnam-participation. Accessed March 19, 2015.

68. Wang, C., et al. (2013). Maternal education and micro-geographic disparities in nutritional status among school-aged 
children in rural northwestern China. PLOS ONE,. doi:10.1371/ journal.pone.0082500.

69. Wellhoner, M., et al. (2011). Maternal and child health in Yushu, Qinghai Province, China. International Journal for Equity in Health, 42(10), 1-10.

70. Wiley, A. S. (2002). Increasing use of prenatal care in Ladakh (India): The roles of ecological and cultural factors. Social Science and Medicine, 55(7), 1089-1102.
71. Zimmermann, M., et al. (2000). Persistence of goiter despite oral iodine supplementation in goitrous children with iron deficiency anemia in Côte d'Ivoire. American Journal of Clinical Nutrition, 71(1), 88-93. 